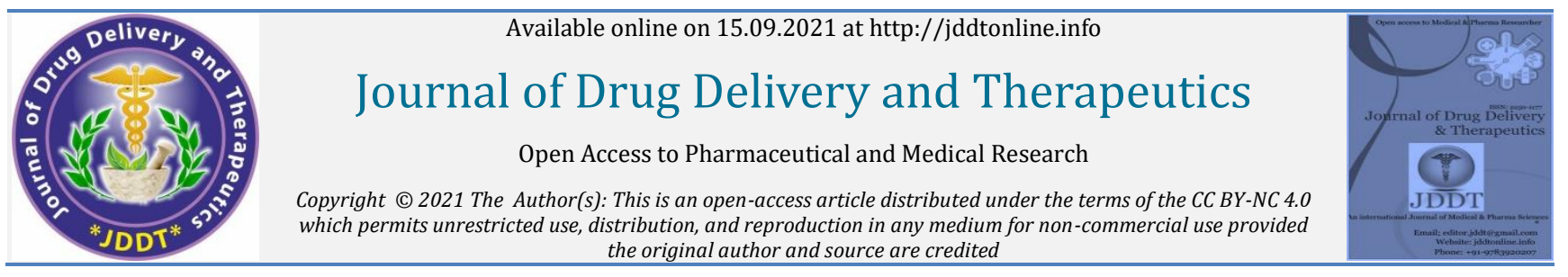

Open Access Full Text Article the original author and source are credited

Research Article

\title{
Hormonal sex reversal technique of Oreochromis niloticus larvae in a tank in the Urban Commune of Kankan, Republic of Guinea
}

Lanan Wassy SOROMOU, Berthin THEA, Yamoussa BANGOURA, Aboubacar Mabinty CAMARA, Samba MAGASSOUBA, Odia Mamady KABA, Youssouf SIDIME

Higher Institute of Sciences and Veterenary Medicine of Dalaba, BP 09, Guinea

Article Info:

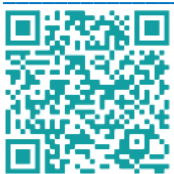

\section{Article History:}

Received 06 July 2021 Reviewed 03 August 2021 Accepted 10 August 2021 Published 15 Sep 2021

\section{Cite this article as:}

Soromou LW, Thea B, Bangoura Y, Camara AM, Magassouba S, Kaba OM, Sidime Y, Hormonal sex reversal technique of Oreochromis niloticus larvae in a tank in the Urban Commune of Kankan Republic of Guinea, Journal of Drug Delivery and Therapeutics. 2021; 11(5):16-22

DOI: http://dx.doi.org/10.22270/jddt.v11i5.4977

*Address for Correspondence:

Dr Lanan Wassy Soromou, Higher Institute of Sciences and Veterenary Medicine of Dalaba, BP 09 Guinea

\author{
Abstract
}

Hormonal sex - reversal is widely recognized as having significant advantage over both manual sexing and hybridization. The present study carried out in the aquaculture center of Kankan aimed at producing monosex male fry of Oreochromis niloticus in order to increase the yield of this species.

During this study, 95 Oreochromis niloticus broodstock including 21 males and 74 females were paired (spawned) in a spawning tank of $135 \mathrm{~m}^{2}$ surface for 15 days. The respective mean weights of the spawners were $448.6 \pm 157.7 \mathrm{~g}$ for males and $406.7 \pm 115.9 \mathrm{~g}$ for females. Hormonal treatment was performed on 900 larvae with an average initial weight of $0.028 \mathrm{~g}$ from the $10^{\text {th }}$ post fertilization to the $38^{\text {th }}$ day in a tank of one (1) $\mathrm{m}^{3}$. The larvae were fed with $1 \mathrm{~kg}$ of imported "Raanan Premium Fish" powdered feed titrated with 40\% protein, mixed in a hormonal solution containing 17- $\alpha$-methyltestosterone and $90 \%$ ethanol with respective doses of $100 \mathrm{mg}$ and $500 \mathrm{ml}$.

At the end of hormonal treatment, 578 fry with a final average weight of $4.5 \mathrm{~g}$ were conducted in a pre-pregnancy tank with a surface area of $50 \mathrm{~m}^{2}$ for 30 days and yielded at the end of pre-pregnancy 501 fry with a final average weight of $13 \mathrm{~g}$, a daily growth rate of 0.22 g, a specific growth rate of $1.7 \%$, a survival rate of $64 \%$ and a mortality rate of $36 \%$. After sex identification (sexing), the rates of hormonal treatment were $83.33 \%$ and $16.66 \%$ for males and females, respectively. In conclusion, the popularization of the results of this study could be considered as an alternative for a production of monosex male population in Oreochromis niloticus that will feed the networks of local producers to improve the production of the species throughout the country.

Keywords: Oreochromis niloticus, hormone, sex, larvae and tank.

\section{INTRODUCTION}

Fisheries and aquaculture are major sources of food for hundreds of millions of people around the world. Today nearly half of the fish consumed in the world comes from fish farming (44.1\%) 1 .

In almost all African countries, fish farming is dominated by Oreochromis niloticus but its farming is limited to subsistence farming and its production is estimated to contribute only around $1.5 \%$ of global production ${ }^{2}$.

In the Republic of Guinea, more than $80 \%$ of fish farmers raise Oreochromis niloticus because of its availability and resilience to fish farming activities, yet the lack of reliable breeding techniques leads to low income levels for fish farmers ${ }^{3}$.

However, in the prefecture of Kankan, more precisely in the urban commune, fish farmers use two methods to control their reproduction: the first, manual sexing based on the sexual dimorphism of the urogenital papilla, is a technique that requires labor and time. In addition, this last method results in errors of 2.7 to $10 \%$ and an elimination of $50 \%$ of the population after three months of rearing. The second, which is rearing in association with predators such as Hemichromis fasciatus and Heterobranchus isopterus, whose role is to consume part of the fry produced during rearing, is a system that requires rearing by age class and therefore a significant number of infrastructures 4 .

On the other hand, although the technique of hormonal inversion is applied on a large scale in the world, it is not yet practiced in the fish farms of Kankan due to the lack of technical skills of the actors involved in this activity. However, this technique consists of producing male fry from synthetic hormones while limiting excessive reproduction in the grow-out structures, which leads to excessive recruitment of juveniles, food competition and the blocking of growth of the farmed stock, which cannot reach market size. Additionally, hormonal inversion is considered a reliable and economically profitable technique, reducing the length of the production cycle and accelerating the growth of the fish. This is why the acquisition of precise knowledge of this practice by fish farmers constitutes a reliable tool to allow an optimization of the performances and a decrease of the production costs in order to increase the level of economic profitability of fish farmers. 


\section{MATERIALS AND METHODS}

\section{Materials}

\section{Brief presentation of the urban commune of Kankan}

The urban commune of Kankan is the second largest city in the Republic of Guinea, after the capital Conakry. It is part of Upper Guinea. It is the capital of the administrative region of Kankan and chief town of the prefecture of Kankan. It covers an area of $334 \mathrm{Km}^{2}$ with a population of 472112 inhabitants. Its geographical position gives it the reputation of a crossroads city in the sub-region. The urban commune of Kankan "Nabaya" is located between $10^{\circ} 30^{\prime}$ North altitude and $9^{\circ} 15^{\prime}$ West longitude.
The city is located on the Milo River watered by other tributaries which are: Séngnè Dèbèkoro, Mafenda, Kokoudouni and Gbountrou.

It is limited :

- to the east by the rural commune of Balandou;

- to the west by the rural commune of Gbérédou Baranama;

- to the north by the rural commune of Karifamoriah;

- to the south by the rural commune of Tinti-Oulén ${ }^{5}$.

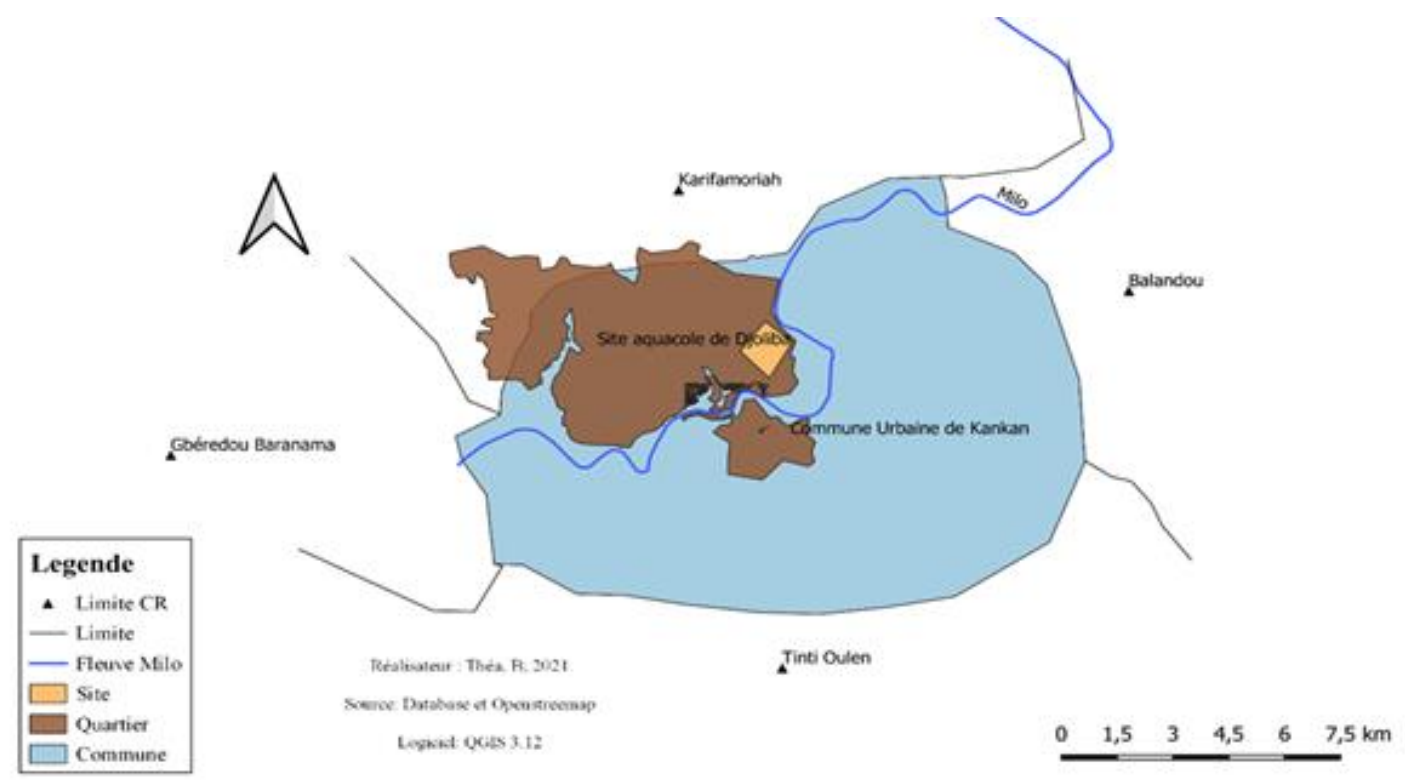

Figure 1: Map of the urban commune of Kankan

\section{Methods}

\section{Production of larvae}

\section{a. Selection of reproducers}

\section{- Males}

The selection of males was made according to three criteria:

- Having a weight superior or equal to $400 \mathrm{~g}$;

- Being in the estrus stage : the males must have milt and for more precision, we applied an abdominal pressure on the genital papilla which must be very reddish;

- Being in good health (no deformation, no wound or spongy aspect on the body).

\section{- Females}

The selection of females was made according to three criteria:

- Having a weight superior or equal to $400 \mathrm{~g}$;

- Being in the estrus stage : for that the females must have eggs; and for more precision we applied an abdominal pressure in order to locate the genital papilla (red or pink);

- Being in good health (no deformation, no wounds on the skin and normal mucus).

\section{b. Pairing}

Sexually mature Oreochromis niloticus spawners were stocked in a 135 squares metre tank at a ratio of three (3) females to one (1) male as the sex ratio. The stocking density was two (2) individuals per square metre increased by a constant of 0.7. The spawners were fed once a day with local powdered feed and a commercial feed "Raanan Grower Fish" pelleted with $30 \%$ crude protein and $4.5 \mathrm{~mm}$ diameter for fifteen (15) days and monitored for spawning.

After spawning, a period of ten (10) days was observed for the nutrient reserves in the yolk sac of the larvae to be absorbed. Larvae were recollected from the spawning tank and returned to the tank where they underwent the hormone treatment for 28 days. The larvae were manually fed with hormonal food (on the fly).

\section{Preparation of the hormonal feed}

\section{a. Preparation of the hormonal solution}

The hormone solution was prepared according to the following protocol:

- Measure $100 \mathrm{mg}$ of hormone 17- $\alpha$-methyltestosterone with a syringe;

- Dilute in $500 \mathrm{ml}$ of ethanol 90\%;

- Shake the obtained solution for 3 minutes manually while securing it. 


\section{b. Incorporation of the hormone solution}

The hormonal solution is then sprayed on 1 kilogram of powdered feed "Raanan Premium Fish" titrated with 40\% protein and mixed with the hands, for 20 minutes until a homogeneous solution is obtained.
The resulting feed is spread on a bag, then dried in the shade at room temperature for 72 hours to evaporate the solvent. The food is then stored in plastic bottles.

\section{Flowchart of the production of the hormonal feed}

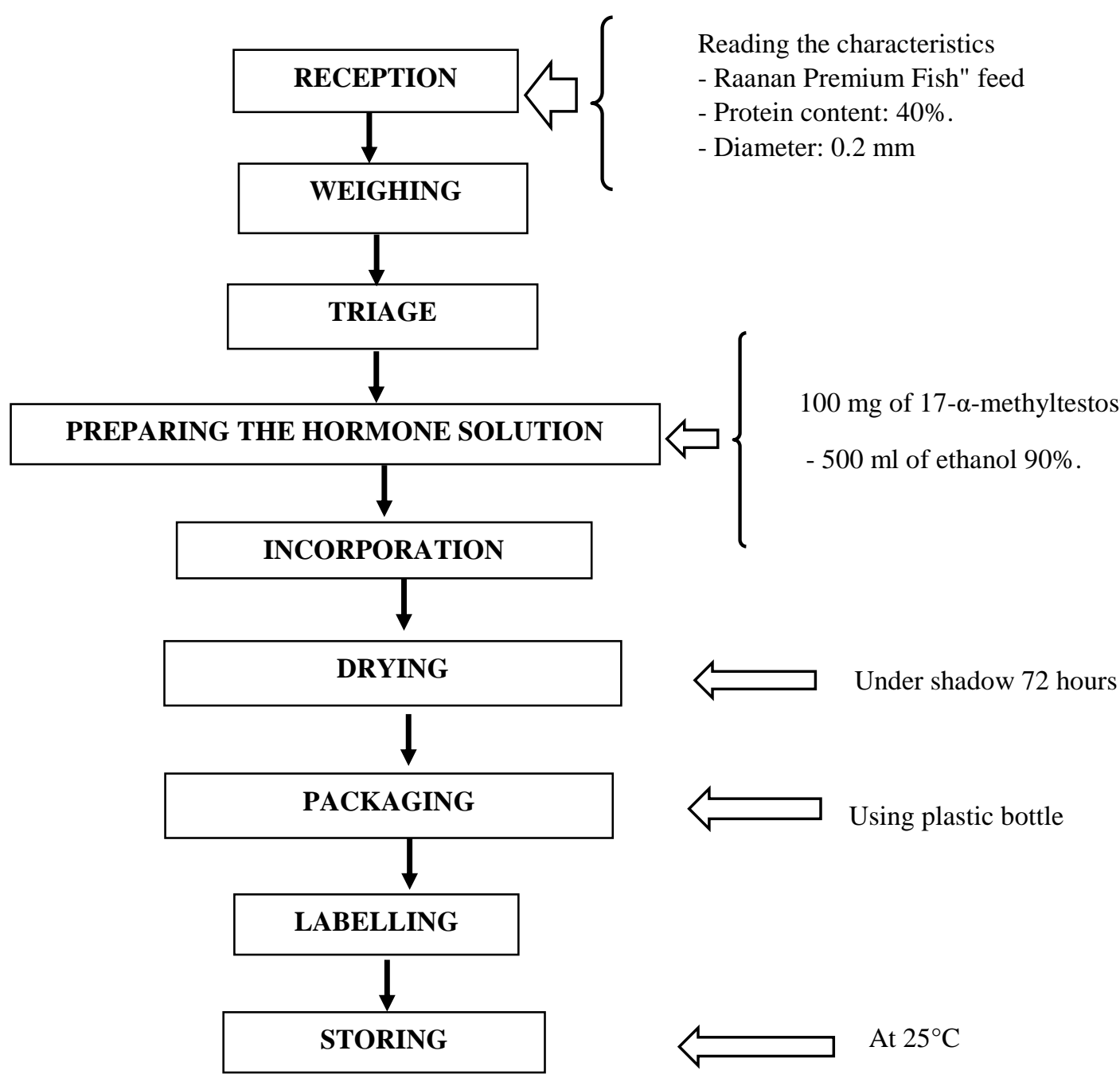

\section{c. Feeding of the larvae to be treated}

The hormonal food was distributed to the larvae, ten (10) days after the absorption of their yolk reserves according to the frequency and period of feeding, six (5) times a day in photoperiod at $10 \mathrm{am}, 12 \mathrm{am}, 2 \mathrm{pm}, 4 \mathrm{pm}$ and $6 \mathrm{pm}$ during 28 days.

\section{Monitoring of the physico-chemical parameters of the farm water}

The measurement of the physico-chemical parameters of the breeding water was made every day at a rate of two measurements, that is to say a first one at $10 \mathrm{am}$ and a second measurement at 5 pm during fifteen (15) days.

However, the measurement of $\mathrm{pH}$, oxygen, temperature and saturation was done using a multifunctional device of the "Handy Polaris" type. Thus, the probe of the device was immersed in the water and kept stable for two (2) to three (3) minutes. The values displayed on the screen are recorded in degrees Celsius for temperature, in $\mathrm{mg} / \mathrm{l}$ for oxygen and in percentage for saturation according to the manufacturer's instruction manual.

\section{Evaluation of zootechnical parameters}

Weekly controls of the weight and satural growth of the larvae were carried out until the end of the hormonal treatment (28 days).

The total biomass and the number of larvae were determined; for this purpose, twenty (20) larvae were randomly taken from the tank with a dip net. Each larva was weighed individually with an electronic scale and measured with a centimeter with the intention of determining the variability of weight per week.

At the end of the hormonal treatment, the tank was emptied of its contents and the harvested fry were quantified, thus from these different data, the zootechnical parameters were calculated to estimate the growth of the larvae and to characterize the efficiency of use of the hormonal feed tested in the experiment. 


\section{a. Body Weight Gain ( BWG)/g}

Expressed in grams, the body weight gain informs about the growth of each larva on average during the rearing period. It is obtained by the difference between the final average weight (Faw) and the initial average weight (Iaw).

\section{BWG $($ g) = Faw - Iaw}

Where: $\mathbf{F a w}=$ final average weight; Iaw = initial average weight.

\section{b. Daily Weight Gain ( DWG)/ (g/d)}

This element allows to appreciate the daily growth of the fish during the rearing period and is obtained with the following formula:

$$
\operatorname{DWG}(\mathrm{g} / \mathbf{j})=(\text { Faw }- \text { Iaw }) / \mathrm{T}
$$

Faw = final weight; Iaw = initial weight; $\mathbf{T}=$ rearing time.

\section{c. Specific Growth Rate (SGR)}

The specific growth rate is the expression of the average percentage increase in weight over the duration of the experiment. It is used to estimate the weight gained each day by the fish as a percentage of its live weight.

$$
\operatorname{SGR}(\% / \mathbf{j})=[(\text { Faw-Iaw } / \text { T }) * 100]
$$

Iaw $=$ initial average weight; Faw $=$ final average weight of fish; $\mathbf{T}=$ rearing time.

\section{d. Survival Rate ( SR)}

The survival rate discloses the number of individuals alive at the end of the experiment compared to the initial number. It is expressed as a percentage according to the following formula:

$$
\mathrm{SR}(\%)=[(\mathrm{Nf} / \mathrm{Ni})] * 100
$$

$\mathrm{N}=$ number of living fish

\section{Monitoring of pre-pregnancy of treated fry}

After the hormone treatment period, 578 fry were transferred to a 50 per square metre pre-pregnancy tank and conducted for a period of 30 days.
These fry were fed a commercial feed "Raanan Feed Fish" in a $2.5 \mathrm{~mm}$ diameter floating pellet with $35 \%$ protein. Daily feed rations were served manually, 3 meals per day at 10:00 am, 2:00 pm and 6:00 pm. At the end of the experiment, 501 pre-pregnant fry were obtained and the final average weight was calculated to determine the average weight gain obtained from all treated fry; then we proceeded to the identification of the sex and the evaluation of the hormonal treatment by calculating the male and female proportions.

\section{Determination of the inversion rate of treated fry}

This determination consisted of randomly sampling 100 fry in the pre-growth tank with a conical net and using methylene blue each fry was identified for sexing. This sexing technique consists in dipping the index finger in a $2 \%$ solution of methylene blue contained in a box and passing it once or twice over the genital papilla of the fry. By observation, the male is characterized by a protruding and elongated iron-shaped genital papilla located below the anal orifice, while the female is characterized by a short genital papilla and presents in its middle a transverse slit located between the anal and urethral orifice. The percentage of male was also calculated using the following formula:

\section{$\%$ Male obtained $=($ number of males obtained $*$ 100)/fish sampled}

\section{Collection and processing of statistical data}

In order to have factual information on the subject, survey and monitoring forms of the physicochemical parameters of the rearing water were designed, and then the data on the measurement and weight of the treated spawners and fry were listed. The different data were analyzed and then processed using the Microsoft Excel Office 2019 spreadsheet.

\section{RESULTS}

\section{Physico-chemical quality of the water}

During the period of hormonal treatment, the main physicochemical parameters including temperature, oxygen and $\mathrm{pH}$ were evaluated during this period of experimentation in order to determine the effect of these parameters on survival, larval growth and sex reversal of the larvae. The results found are presented in the figure below.

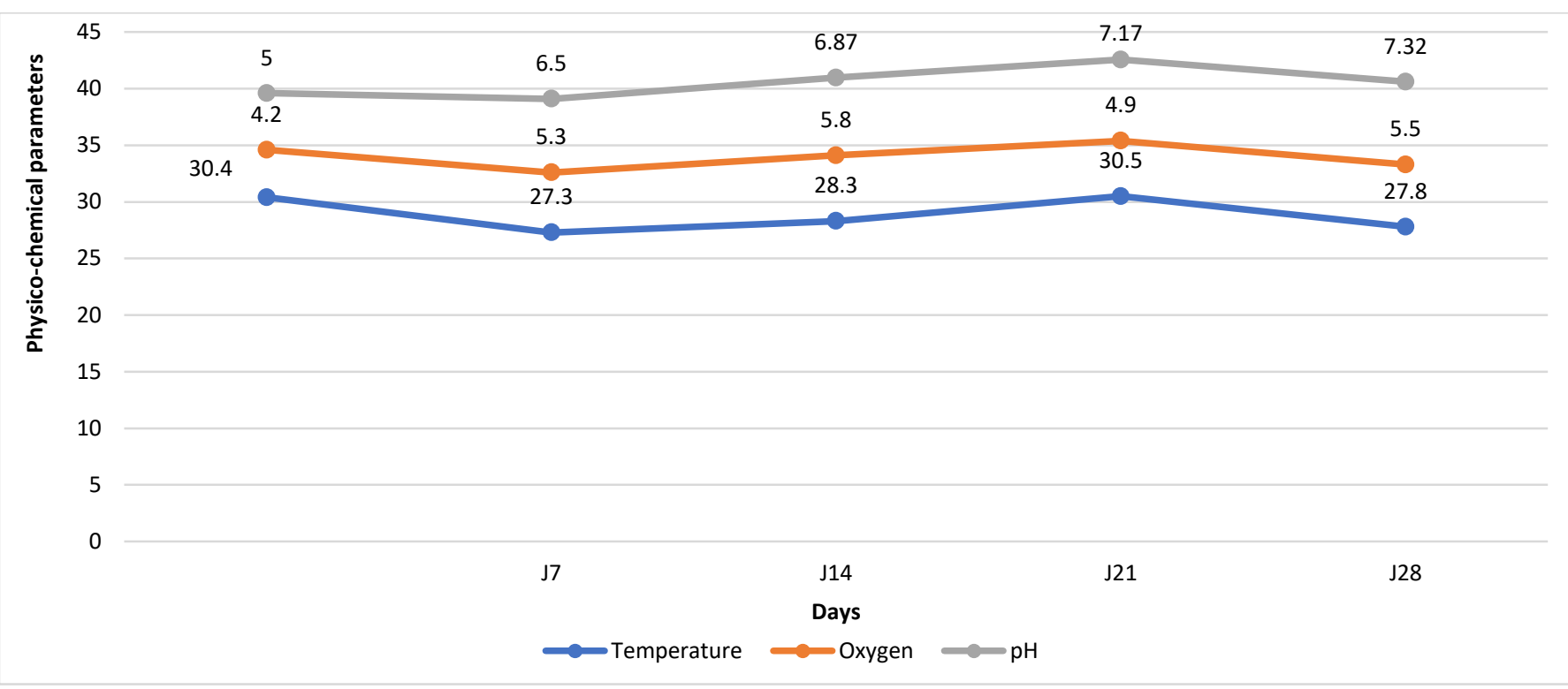

Figure 2: Weekly variations of physico-chemical parameters 


\section{Evaluation of zootechnical parameters}

\section{a. Growth}

During the period of hormonal treatment and pre-pregnancy of the treated fry, weekly controls on weight and saturation growth were carried out, the results we obtained are presented in the figure 3 .

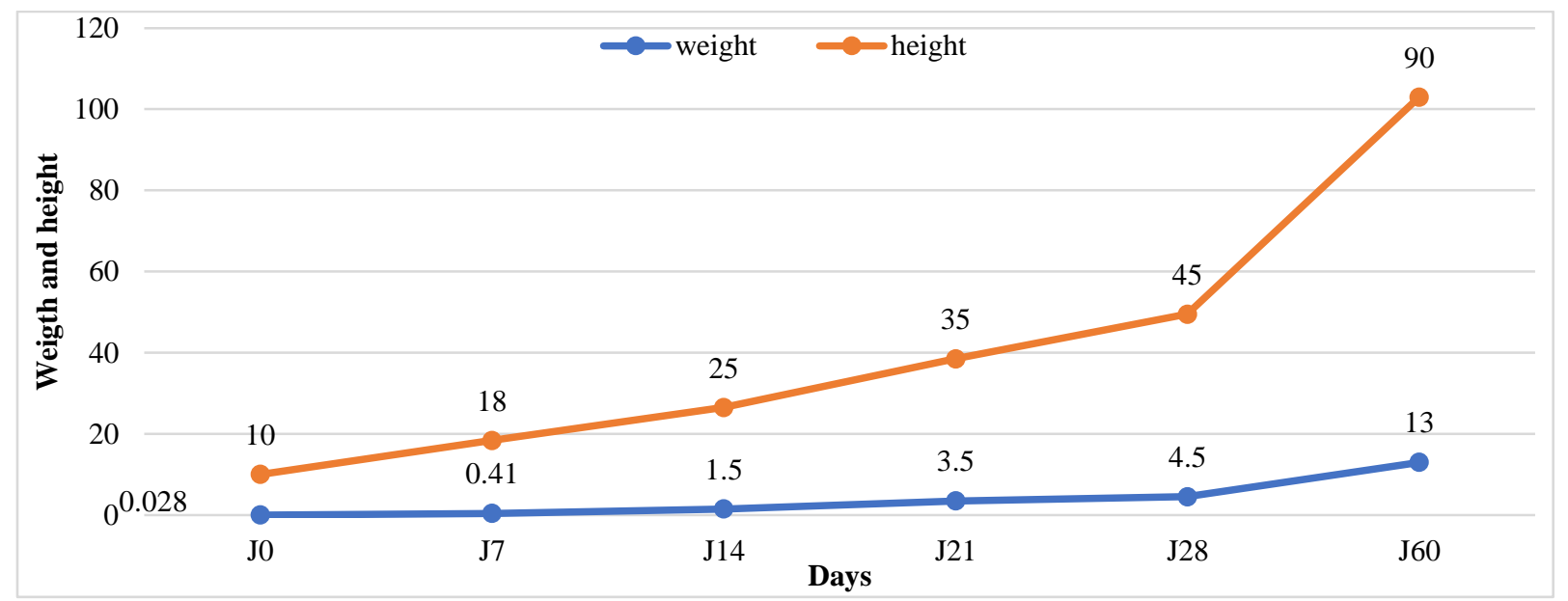

Figure 3: Weekly evolution of average weight and height during the experiment

\section{b. Zootechnical indices}

At the end of the hormonal treatment, the treated fry were taken for pre-pregnancy and the zootechnical parameters were determined in order to estimate the growth of the treated larvae and to characterize the efficiency of use of the hormonal feed tested, the results found are recorded in the following table.

\section{Table I: Animal health indices evaluated}

\begin{tabular}{|l|l|}
\hline \multicolumn{2}{|c|}{ Zootechnical indices } \\
\hline Initial weight (g) & 0,028 \\
\hline Final weight (g) & 13 \\
\hline Weight gain (g) & 13 \\
\hline Daily weight gain (g/d) & 0,22 \\
\hline Specific Growth Rate (\%/d) & 1,7 \\
\hline Survival rate (\%) 64 & 64 \\
\hline
\end{tabular}

\section{Monitoring of pre-pregnancy}

After the period of hormonal treatment of the fry, a total fishing was carried out and the caught fry were stocked in the pre-pregnancy tank and monitored for one month; the results we reached after pre-pregnancy are mentioned in the figure below:

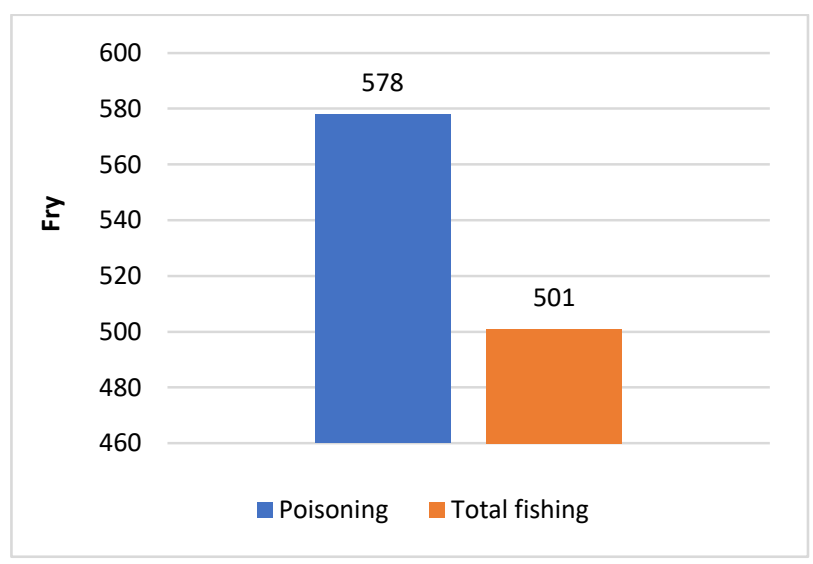

Figure 4: Monitoring of pre-growth of treated fry

\section{Sex Determination}

At the end of pre-pregnancy, we proceeded to the identification of the sex of the treated fry to determine the rate of male and female inversion in order to reassure ourselves of the success of the hormonal treatment; the results are mentioned in the figure 5.

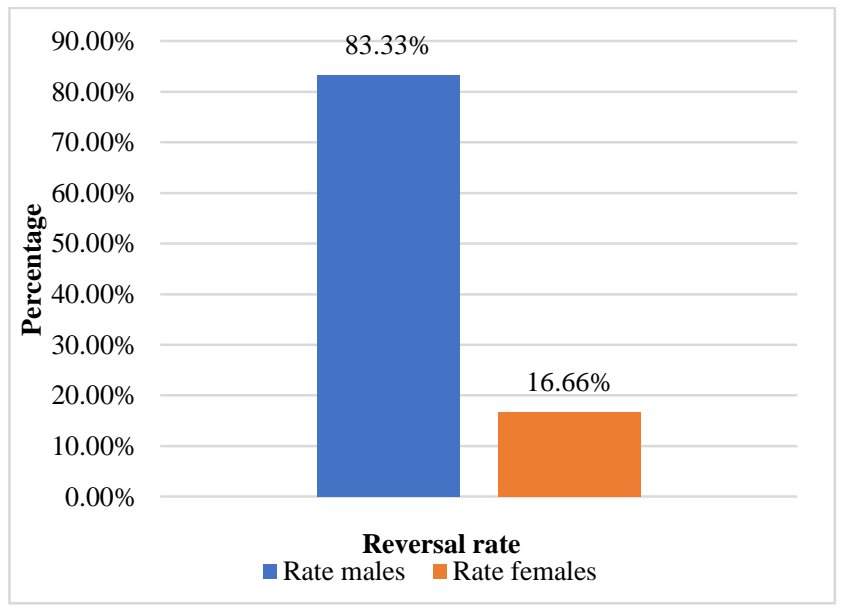

Figure 5: Proportion of males and females after sex reversal

\section{DISCUSSION}

This study was one of the first in the Republic of Guinea to highlight the production of monosex male fry of Oreochromis niloticus.

In general, the physico-chemical parameters of the water are within the recommended optimal range of values. The monitoring of weekly average temperatures recorded in the morning and evening during the hormonal treatment (larval monitoring) indicates a minimum of $27.3^{\circ} \mathrm{C}$ and a maximum of $30.5^{\circ} \mathrm{C}$ with an observed average of $28.8 \pm 1.27^{\circ} \mathrm{C}$. The temperature values recorded during this trial are comparable to those obtained by ${ }^{6}$, with ranges of $\left(26-30^{\circ} \mathrm{C}\right)$ for the growth of Oreochromis niloticus. Dissolved oxygen concentrations measured during the hormone treatment 
period indicate a minimum of $4.2 \mathrm{mg} / \mathrm{l}$ and a maximum of $5.8 \mathrm{mg} / \mathrm{l}$ with an average of $5.06 \pm 0.40 \mathrm{mg} / \mathrm{l}$. These recorded results are close to what was reported by ${ }^{4}$, who said that the dissolved oxygen level necessary for the growth of Oreochromis niloticus is $5 \mathrm{mg} / \mathrm{l}$. However, low oxygen values are recorded in the mornings and high values at the end of the day. The variation of these values could be explained by the remains of food which were deposited at the bottom of the tank, the waste of the fish thus causing a pollution of the environment and the photosynthesis which is almost null at night whereas the breathing is continuous involving an important consumption and a production of carbon dioxide from the night to the dawn. The variation of $\mathrm{pH}$ observed during the hormonal treatment indicates a minimum of 6.87 and a maximum of 7.32 with an average of $7.11 \pm 0.11$. These obtained results are not in agreement with those of 7 , who say that the $\mathrm{p}^{\mathrm{H}}$ values of the rearing waters of the different treatments are rather neutral. The recorded values are on average $7.56 \pm 0.08$, with a minimum of 7.48 and a maximum of 7.67. The discrepancy of these results would be related to the nature of the water used, the increase of $\mathrm{CO}_{2}$ due to the concentration of individuals in the environment favoring the variation of the $\mathrm{pH}$

The growth monitoring carried out during the different control fisheries shows a positive evolution of the average body weights during the experiment. From an average weight of $0.028 \mathrm{~g}$ at the time of stocking, we obtained fry with an average final weight of $4.5 \mathrm{~g}$ at the end of the hormonal treatment in 4 weeks (28 days). As for the pregrowth, from fry with an average weight of $4.5 \mathrm{~g}$, we produced fingerlings with an average final weight of about $13 \mathrm{~g}$.

These obtained results are contrary with those obtained by 8 , in Ivory Coast, who produced $1 \mathrm{~g}$ fry from a weight of 0.01 $\mathrm{g}$ for 28 days and $36 \mathrm{~g}$ fingerlings from a weight of $1 \mathrm{~g}$ in 70 days. The dissimilarity of these results would be due to the duration of the pre-pregnancy of the treated fingerlings which was extended over a period of 30 days, the feeding frequency of the fingerlings during the pre-pregnancy phase which was 3 times per day and the age-related feeding competition of the treated fingerlings. In contrast in the classical production cycle from a weight of $5 \mathrm{~g}$, fingerlings of $25 \mathrm{~g}$ are produced in 90 days ( 3 months) ${ }^{9}$. It should be noted that hormone-treated fry show better growth performance. However, the pattern of size evolution is similar to that of body weight. The average size at stocking was $10 \mathrm{~mm}$ and a final average size of $90 \mathrm{~mm}$ was obtained at the end of pregrowth.

The daily weight gain and specific growth rate obtained during the 60 days are $0.22 \mathrm{~g} / \mathrm{d}$ and $1.7 \%$ respectively. These values found here are different from those recorded by 7 , who obtained an average daily weight gain of $0.15 \mathrm{~g} / \mathrm{d}$ and a specific growth rate of $2.92 \%$. The discrepancy in his results would be related by a thermal phenomenon, as low temperatures induce a decrease in feed intake which results in low fry growth.The average survival rate recorded in this study was $64 \%$. This value of survival rate does not corroborate that of 10 , which states that the survival rate of Oreochromis niloticus generally accepted in breeding is more than $90 \%$. The difference in survival rate could be due to the frequency of water renewal in the tank, the non respect of the stocking density of the fry which is 20 individuals $/ \mathrm{m}^{2}$, the fluctuation of the physicochemical parameters notably the temperature and the transport on the one hand and on the other hand by the great heterogeneity of the weight and the size of the treated fry; which translates into an aggressive behavior going up to cannibalism. During the prepregnancy phase, 578 fry were placed in tanks with the objective of identifying sex. After this phase, a control fishing was carried out. Thus we found a decrease in the number of fry, from 578 to 501 , a reduction of $13 \%$. This would be due not only to the climatic conditions, but also to the high stocking density which would lead to cases of cannibalism related to the heterogeneity of the size and weight of the treated fry. These results obtained are contrary to the results recorded in the work of 8 , in Ivory Coast who conducted 500 monosex fry in the pre-pregnancy phase; with a density of 20 individuals/m2 and a feeding frequency of 5 meals per day during 6 weeks and obtained at the end of the pre-pregnancy 490 fry that is to say a dimunition of $2 \%$ and a survival rate of $98 \%$

The hormonal treatment applied during this study showed a masculinization rate equal to $83.33 \%$. The results obtained are superior in comparison with the work of 7 in their study "Sexual inversion in Oreochromis niloticus from the National Research and Development Station of Fisheries and Aquaculture in Algeria" which produced 65.33\% of monosex male fry of Oreochromis niloticus, with concentrations of 40 mg of hormone/ $\mathrm{kg}$ of food. This discrepancy in results could can be explained by the fact that we did not use the same hormones, but also the same quantities of hormones. However, our results are lower than the rate of masculinization recorded in the work of [8] in Ivory Coast, which is $100 \%$. This author states that he obtained a hormone solution by dissolving $70 \mathrm{mg}$ of hormone in $100 \mathrm{ml}$ of $96 \%$ ethanol and his daily food rations were 12 meals. The difference in the results would be related to the quality of the hormone and alcohol used for the dosage of the hormone solution, the frequency of distribution of the hormone feed which was 5 times per day and to the fish fry production systems.

\section{CONCLUSION}

In conclusion, the present study produced male monosex fry of Oreochromis niloticus by using artificial hormone 17- $\alpha$ methyltestosterone in the larval diet. Thus, we would like to continue this research to establish an ideal treatment regimen by replacing the synthetic hormone with plants with androgenic properties for economically profitable and environmentally sustainable production.

\section{Conflicts of interest}

The authors declare that there are no conflicts of interest.

\section{Contribution of the authors}

Berthin THEA, Samba MAGASSOUBA and Odia Mamady KABA participated in the conception of the subject, the activities and the collection of donations in the field. Youssouf SIDIME, Lanan Wassy SOROMOU, Yamoussa BANGOURA and Aboubacar Mabinty CAMARA participated in the writing and correction of the manuscript.

\section{Acknowledgements}

We would like to thank the authorities of Higher Institute of Sciences and Veterinary Medicine for their contributions and support in our research work. We express our gratitude to the Fish Farming Project of the Djoliba International Group of Kankan and the Guinea Halieute Consulting for their support.

\section{REFERENCES}

[1] FAO, 2016. La situation des pêches et de l'aquaculture. Contribution à la securité alimentaire et à la nutrition de tous. Rome, Italie 105.p. http//www.org Consulté le 25/09/ 2020 à 23 heures 15 minutes 30 secondes. 
[2] FAO, 2011. Analyse Prospective du développement de l'aquaculture : méthode Delphi. FAO document technique sur les pêche et l'aquaculture. $\mathrm{N}^{\circ} 521, \mathrm{FAO} 77 \mathrm{p}$.

[3] APDRA-PDRP-GF (2017). Association Pisciculture de Développement Rural en Afrique-Projet de Développement de la Rizi-Pisciculture en Guinée Forestière. Guide de la pisciculture paysanne en Guinée forestière. Direction Nationale de la Pisciculture, Agence Française de Développement et Union Européenne. P.97.

[4] Ouédraogo, C.R.N. 2009. Inversion hormonale du sexe par la methyltestostérone et l'ethynyleostradiol chez le Tilapia Oreochromis niloticus. Mémoire de Diplôme d'Etudes Approfondies. Université Polytechnique de Bobodioulasso: p.46.

[5] Recensement Général de la Population Humaine 2014.

[6] Khemis, S, Maamri, S. Inversion sexuelle chez Oreochromis niloticus de la Station Nationale de la Recherche et du Développement de la Pêche et de l'Aquaculture (CNRDPA)
Hassiben Abdellah, Ouargla. Mémoire de Master Professionnel. Université Kasdi-Merbah Ouargla, Faculté des Sciences de la Nature et de la Vie, Département des Sciences Biologiques. Spécialité : Aquaculture. $2019 ; 34$ p.

[7] Saar, S.M., Kabrè, A.J.T and Niass, F., Régime alimentaire du mulet jaune (Mugil cephalus, Linneaus, 1758, Mugilidae) dans l'estuaire du fleuve Sénégal. Journal of Biosciences, 2013; 71:5663-5672. https://doi.org/10.4314/jab.v71i1.98809

[8] Koné, Y., 2016. Inversion hormonale du sexe par la 17-alphamethyltestostérone chez le tilapia (Oreochromis niloticus): souche Bouaké Côte d'Ivoire: Memoire de Master- UFRSGE. Universite Nangui Abrogoua Côte d'Ivoire.

[9] Adjanké, A. Technique de production d'alevins et gestion de ferme piscicole. Togo. Coordination Togolaise des Organisations Paysannes et de Producteurs Agricoles (CTOPPA). 2011 ; p.39.

[10] Lazard, J., La pisciculture des tilapias. Cahiers Agricuttures. 2009; pp. 171-182. https://doi.org/10.1684/agr.2009.0305 